\title{
LUMINESCENCE OF ROCK-FORMING QUARTZ OF THE GRANITOIDS FROM THE KOLYVAN-TOMSK FOLDED BELT IN RELATION TO FACIES FEATURES OF MASSIF FORMATION
}

\author{
Nina Nikolayevna BOROZNOVSKAYA * and Tatyana Stepanovna NEBERA
}

National Research Tomsk State University, 634050 Tomsk, 36 Lenin Ave., Russia

*Corresponding author's e-mail: boroznovskaya@mail.ru

\begin{tabular}{l} 
ARTICLE INFO \\
\hline Article history: \\
Received 8 October 2017 \\
Accepted 7 March 2018 \\
Available online 20 March 2018 \\
\hline
\end{tabular}

Keywords:

Granitoids

Kolyvan-Tomsk folded belt

Quartz luminescence

\begin{abstract}
The paper studies the connection between the X-ray and thermo quartz luminescence, the massif formation facie features and differentiation of magmatic melt features, using the example of the Permian-Triassic granitoids from the Kolyvan-Tomsk folded belt (KTFB; the Kolyvan, the Barlak, the $\mathrm{Ob}$, and the Novosibirsk rock massifs). The X-ray luminescence optical spectra and the thermoluminescence curves of quartz from the massifs listed above are obtained. The quartz luminescence is proven to be linked to the features of the magmatic melt differentiation. It is shown that the equivalence of the X-ray- and the thermoluminescence of granitoids quartz from different massifs are the result of similar conditions and mechanisms of the granitoids formation with close establishment periods. The obtained data make it possible to consider the KTFB granitoid magmatism as a result of natural magmatic differentiation of the original magma and to use the quartz emission spectra for typing granitoid massifs. The individuality of the Novosibirsk massif quartz, manifested in intense luminescence of $\mathrm{Fe}^{3+}$, defects of $\mathrm{O} *(370 \mathrm{~nm})$ and thermoluminescence (TL) at $180-220^{\circ} \mathrm{C}$, can be associated with high fugacity of oxygen, increased temperature and rate of mineral formation in rock collapse mode under tectonically active zone conditions. At the same time, the obtained data provides evidence for the differences in the leucocratic magmatism of the area, allowing differentiation of the Kolyvan-Tomsk folded belt leucogranites into the leucogranites of the Novosibirsk massif (Mo-W type of mineralization) and the leucogranites of the Kolyvan and the Barlak massifs characterized by rare metal mineralization (stannic-tungstic-beryllic with silver).
\end{abstract}

\section{INTRODUCTION}

The Permian-Triassic period of the Central Asia geological evolution draws particular attention due to the emergence of the Siberian superplume (Dobretsov, 1997). This study is aimed at resolving one of the most important issues of modern geology - defining the conditions of mineralization during granitoid intrusive bodies formation in the areas of island-arc collision and subcontinental terrains (Nebera et al., 2012). This research originates from earlier studies of the authors on the Mg-Fe micas composition (Nebera et al., 2012) and the luminescence of feldspars (Boroznovskaya et al., 2012). In this study, the authors aimed to show the informative value of the luminescent features of quartz, ubiquitous rockforming mineral, in the context of solving this problem.

\section{STUDY SUBJECT \\ BRIEF GEOLOGICAL DESCRIPTION}

The Kolyvan-Tomsk folded belt (KTFB), where granitoids are studied, is located in the Extreme North-West of the Altai-Sayan folded region, being its youngest (Late Hercinian) region; it is a part of the
Central West Siberian fold system. In the geodynamic plan, the KTFB corresponds to the back-arc basin. Beginning with the Devonian, the KTFB developed in the regime of an active continental margin. Within its boundaries are island arcs, the Novosibirsk trough and back-arc basins, which survived later accretion and collision. We are primarily interested in the Novosibirsk depression. The syncline is composed of flyschoid-shale-sandy-siltstone lower-Carbonaceous $\left(\mathrm{C}_{1} \mathrm{t}-\mathrm{v}\right)$ and Upper Devonian $\left(\mathrm{D}_{3} \mathrm{fm}\right)$ sediments and is complicated by a number of small depressions made by carbonate-sedimentary rocks. Granitoid massifs of permo-Triassic age are confined to dome-shaped uplifts, the formation of which is associated with collision. The Ob, Novosibirsk, Kolyvan, and Barlak massifs represents the granitoid magmatism of the permo-Triassic age of the KTFB. These granitoids form a chain of arrays elongated according to the strike of the main structures (Fig. 1).

There is no clear idea of the evolutionary patterns of deep magma chambers and the features of magmatic differentiation of the whole granitoid complex. There is also no consensus on the genesis of granitoids from the Kolyvan-Tomsk folded belt. There 


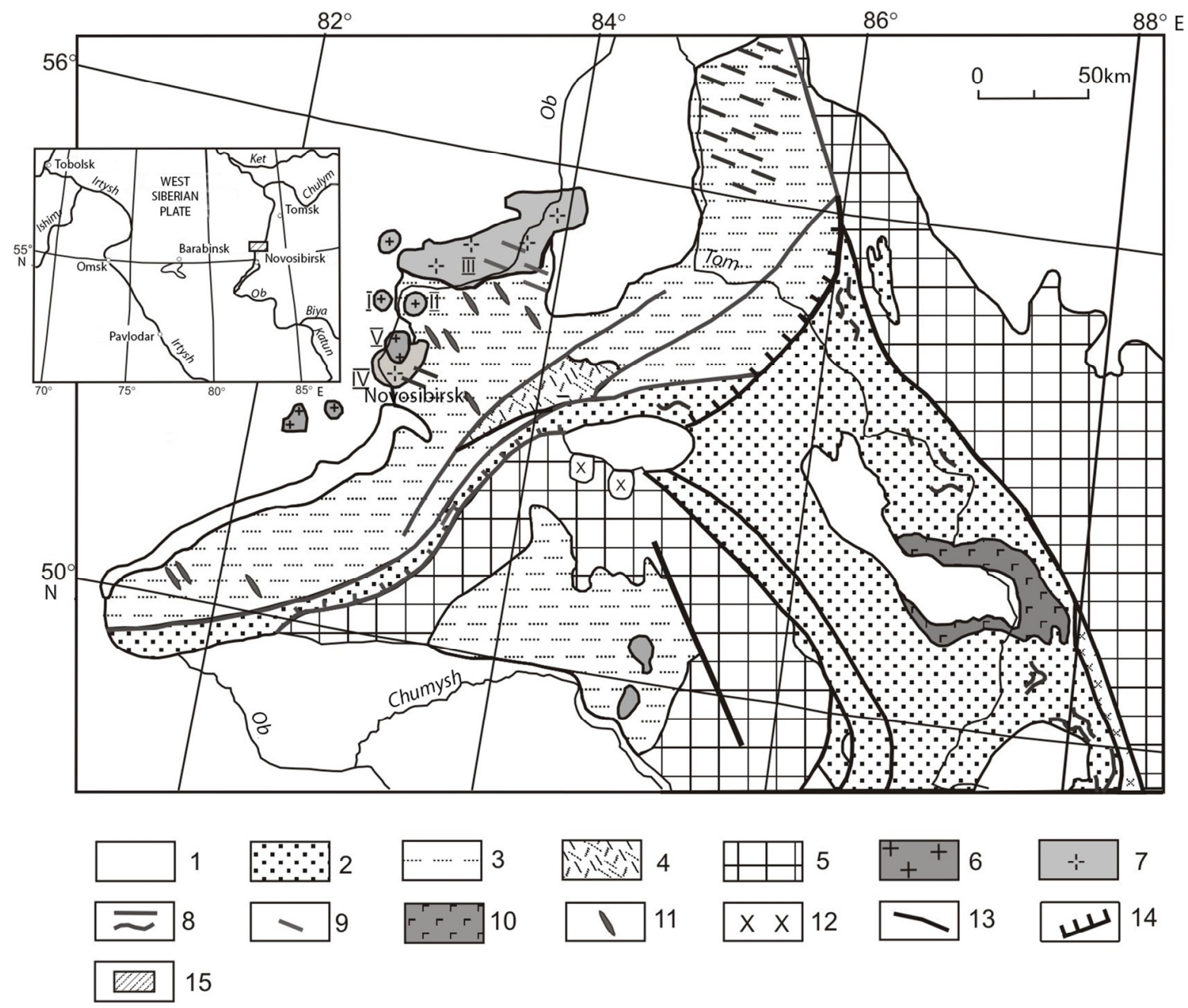

Fig. 1 Allocation scheme of major manifestations of the Permian-Triassic granitod magmatism of KTFB (Nebera et al., 2012).

Deposits: 1 - Meso-Cenozoic, 2 - Middle to Late Paleozoic terrigenous, 3 -Middle Paleozoic terrigenous of KTFB and Khmelevsk depression, 4 - Devonian effusive sedimentary, 5 - Early Paleozoic and Pre-Cambrean; 6 - leucogranites of the Barlak complex $\left(\mathrm{T}_{2-3}\right)$ : massifs I - the Kolyvan, II - the Barlak, V - Mochishche stock (northern part of the Novosibirsk massif); 7 - granitoids of the Ob Area complex $\left(\mathrm{P}_{2}-\mathrm{T}_{1}\right)$ : massifs III - the $\mathrm{Ob}$, IV - Novosibirsk; 8 - gabbro-doleritic sills $\left(\mathrm{T}_{1}\right) ; 9$ - dykes of the Novosibirsk monzodiorite and dolerite complex $\left(\mathrm{T}_{1}\right) ; 10$ - basalts of the Saltymak complex $\left(\mathrm{T}_{1}\right) ; 11$ - intrusive bodies of the Tashara picrate and dolerite complex $\left(\mathrm{P}_{2}\right) ; 12$ - Middle to Late Paleozoic granitoids; 13 - faults; 14 - thrust faults, 15 - study area.

are different estimates of their ore resources and cross-sectional profiles of separate massifs (Nuvar'eva, 1968; Sotnikov et al., 1999; Khomichev et al., 2003; Khomichev, 2007). Some researchers suggest that granitod magmatism should be considered as the result of natural magmatic differentiation of the parental basaltic magma (Khomichev, 2007). According to another point of view (Sotnikov et al., 1999), the Barlak, the Kolyvan massifs and, presumably, the northern part of the Novosibirsk massif (Mochishche stock) should be distinguished as a separate complex - the Barlak leucogranite (T2-3), characterized by rare metal mineralization (stannic-tungstic-beryllic with silver) (Fig. 1).

\section{BRIEF PETROCHEMICAL AND GEOCHEMICAL CHARACTERISTICS OF GRANITOIDS OF THE KOLYVAN-TOMSK FOLDED BELT}

Analysis of petrochemical characteristics of granitoids in the study area showed that the main feature is their increased alkalinity with increased potassium (Neber et al., 2012). The rocks are peraluminous, granitoids of a "mixed type", having the petrochemical features of S- and A-type granitoids. And there are granitoids of the Kolyvan and Barlak massifs in the A-type field. Although the rocks of the $\mathrm{Ob}$ and Novosibirsk massifs show the S-type granitoids features, they are closer to I-granites (more mafic, contain hornblende, accessory magnetite, orthite, high degree of oxidation of iron, are formed at high oxygen fugacity, high concentration of $\mathrm{Ba}, \mathrm{Sr}$, normal or high concentration 
of $\mathrm{Ca}$ ). In addition, the $\mathrm{Ob}$ and Novosibirsk massifs granitoids have a number of geochemical characteristics that can be classified as latite type (Khomichov et al., 2003). They correspond to the subalkaline series at $\mathrm{K}_{2} \mathrm{O}>\mathrm{Na}_{2} \mathrm{O}$, are characterized by increased magnesia, high concentrations of $\mathrm{Ni}, \mathrm{Cr}, \mathrm{Ba}$, $\mathrm{Sr}$, low $\mathrm{Rb}$ and increased $\mathrm{K} / \mathrm{Rb}$ ratios. Leucogranites of the Kolyvan and Barlak massifs are characterized by high concentration of $\mathrm{Rb}$, concentrations of $\mathrm{Ba}$ and $\mathrm{Sr}$ decrease drastically, they are also enriched in $\mathrm{Be}$, Cs. All this brings them closer to Li-F granites of increased alkalinity, according to the same classification. The degree of rare metal specialization increases from the Novosibirsk Massif to the Kolyvan Massif leucogranites.

\section{STUDY METHODS, MATERIALS AND EQUIPMENT LUMINESCENCE OF MINERALS AS A SOURCE OF GENETIC INFORMATION}

Luminescence is a physical property of a mineral, which reflects its crystallochemical features, formation and transformation conditions. Luminescence intensity is related to the density of luminescence centers within the mineral, which, in turn, depends on the condition of the mineral formation, i.e. temperature, pressure, acid and redox conditions. Therefore, luminescence is a typomorphic characteristic, containing genetic information (Boroznovskaya et al., 2012). In the course of studying any geological object, it is important to define the rock-forming mineral, which luminescence will provide genetic information. Quartz is characterized by simple stoichiometry and structure. However, optical spectroscopy methods (including luminescent ones) allow revealing its complex structural and chemical states at the electronic level (Boroznovskaya et al., 2015; Boroznovskaya et al., 2016; Götze et al., 2001; Kuznetsov and Tarashchan, 1988; Lyutoev, 2008; Pagel et al., 2000; Pagonis et al., 2007; Pogorelov et al., 1981; Votyakov et al., 1993). Microscopic structural imperfection of quartz manifests itself through the luminescence centers, being related to the parameters of its genesis (Demars et al., 1996; Rink et al., 1993; Rokachuk, 2006). Studying quartz luminescence by identifying specific features of fine atomic and electronic structure can provide genetic information.

\section{BRIEF DESCRIPTION OF QUARTZ STRUCTURAL IMPERFECTIONS AND LUMINESCENCE CENTERS}

The quartz luminescence spectra depend on presence and proportion of extrinsic and intrinsic mineral structure defects. The most common trace element in quartz is aluminium. Structural impurities caused by aluminium can be found in quartz crystals of any genesis, and their density, depending on the conditions of the mineral formation and metamorphism, if there have been such processes, according to certain studies, ranges from 2 to $500 \mathrm{ppm}$ (Rakov and Moiseev, 1999). Trivalent aluminium forms tetrahedral bonds with three oxygen ions, leaving the bond with the fourth ion uncompensated. $\mathrm{Li}^{+}$or $\mathrm{Na}^{+}$cations, located within structural channels, may serve as charge compensators (Kuznetsov and Tarashchan, 1988; Götze et al., 2001). Structural impurities caused by $\mathrm{Ge}^{3+}, \mathrm{Fe}^{3+}, \mathrm{Mn}^{2+}$ etc. can also be found. The defects, which are not related to trace elements included into the quartz structure, are various. First of all, these include oxygen and silicon vacancies. Tetrahedric structures with a silicon vacancy contain centers of the $\mathrm{O}^{-}$-type - various defect electrons of the oxygen atoms (Gorobets and Rogozhin, 2001). Oxygen vacancies (so-called E-centers) are formed due to natural ionizing radiation. Naturally occurring quartz usually contains non-paramagnetic forms of these defects, which can be forced to the $E_{1}$ paramagnetic state through annealing (Jani et al., 1983). Nonbridging oxygen can also be formed within the quartz structure. Ideally, each oxygen atom within the silica structure is bridging, which means that it is connected with two silicium atoms. Nonbridging oxygen atom has bond with one silicium atom. A negatively charged hole center can also be associated with it. Quartz crystals of any genesis contain certain amounts of self-trapped excitons - structural imperfections, including an electron-hole pair, which is a Frenkel defect (an interstitial-vacancy pair, in this case consisting of an oxygen vacancy and a peroxide bridge). They are formed due to strong interactions of electrons and phonons in SiO2 (Hayes, 1990). All these imperfections form the basis for the emergence of luminescence centers. We will refer to all luminescence centers based on intrinsic defects as excited states of oxygen $\mathrm{O}^{*}$.

\section{MATERIALS}

According to the composition and quantity of dark-colored minerals, the KTFB granitoids are traditionally divided into two groups. These are biotite-amphibole, biotite granites, granodiorites $(\mathrm{Ob}$, Novosibirsk massifs) and biotite, biotite-muscovite leucocratic granites (Kolyvan, Barlak massifs).

In the $\mathrm{Ob}$ massif rocks of several intrusive phases are distinguished in the structure of the massif (Bazhenov et al., 2003). The first phase is coarsegrained porphyritic biotite granites, amphibole-biotite granites, granosyenites, granodiorites. The second phase of injection time is close to the main phase and is represented by medium- and fine-grained leucocratic granites with rare potassium feldspar phenocrysts. The third (final) phase is low-power dikes, aplite veins, aplite-like granites. The main mass area is composed of the first phase rocks. The granitoids of the central part of the intrusion and the endocontact facies are distinguished. Endocontact facies were penetrated by Novobibeevsky quarry $(\mathrm{Nb})$. Porphyritic structure is typical for all rocks due to large (up to $8-10 \mathrm{~cm}$ ) orthoclase precipitates (Nebera and Boroznovskaya, 2009). 
The Novosibirsk massif is composed of porphyritic biotite granites, granosyenites and biotitecontaining leucogranites (Mochishche stock).

The Barlak and Kolyvan massifs granitoids are almost indistinguishable in petrographic characterristics. The main area of the massifs is mediumgrained biotite leucogranites. The endocontact facies are represented by biotite and two-mica granites.

\section{SAMPLING AND PREPARATION OF SAMPLES FOR ANALYSIS}

Quartz mono fractions from three intrusive phases of the $\mathrm{Ob}$ massif (44 samples, including endocontact), from biotite granites and granosyenites of the Novosibirsk Massif (20 samples) and leucogranites of the Kolyvan and Barlak massifs (20 samples), and from the leucogranites of the Mochishche stock (Novosibirsk massif) (10 samples) were selected for clarifying the influence of the formation conditions on the spectral composition of the emitted luminescence. Samples of quartz monofraction of $20 \mathrm{mg}$ for XRL analysis and $20 \mathrm{mg}$ for TL analysis were taken from rock crushed sample (0.2-0.5 mm fraction). The quartz grains were handpicked under a binocular. The purity of doubtful grains in the samples was controlled with immersion liquid.

\section{EQUIPMENT AND METHODS OF ANALYSIS}

Spectra of X-ray luminescence (XRL) are obtained using a self-constructed machinery. The machinery has been designed and created by the Institute of Atmospheric Optics of the Siberian Branch of Russian Academy of Sciences. The machinery used computer-controlled MDR-12 monochromator. Luminescence is excited by BSV-2 X-ray tube with Mo-target cathode from URS-55 device $(\mathrm{U}=50 \mathrm{kV}, \mathrm{I}=10 \mathrm{~mA})$. Application of PMT-79, PMT-100 and changeable diffraction gratings with operating regions of 200-500 nm and 350-1000 nm allowed to cover the spectral range from 300 to $800 \mathrm{~nm}$. To record the range of $600-800 \mathrm{~nm}$, the cutoff filter Thorlabs FELH0600 is used. The measurements are carried out by continuous scanning of the selected spectral range at the rate of $1 \mathrm{~nm} / \mathrm{s}$. The intensity of the radiation is measured in relative units. The reproducibility of the spectra is monitored by repeated measurement and it was $95 \%$.

Integral thermoluminescence (TL) is recorded using the device, assembled according to the circuit for direct current measurement. The thermoluminoscope control system (TSL) includes highvoltage adjustable power supply unit for the photomultiplier tube (PMT-39 in light-protective thermally insulated chamber, spectral range 200$600 \mathrm{~nm}$; this allowed us not to use optical filters), two direct-current amplifiers for the photomultiplier and the thermocouple units; oven-heating control unit; unit for the PMT and the thermocouple signals digitalization and transfer to the computer. Heating unit consists of the oven and the temperature controller, measuring the temperature by a chromelalumel thermocouple. The thermocouple and the heating unit are graduated by the reference points $\left(29.76{ }^{\circ} \mathrm{C}\right.$ - melting point $\mathrm{Ga}, 156.6^{\circ} \mathrm{C}$ - solidification point in, $231.9^{\circ} \mathrm{C}$ - solidification point $\mathrm{Sn}, 419.5^{\circ} \mathrm{C}$ solidification point $\mathrm{Zn}$ ). Control of points is visual. The sample heating rate is linear, equal to $3.8-4{ }^{\circ} \mathrm{C}$ per second. For TL analysis, samples that have not been exposed to artificial irradiation are used, i.e. the natural TL is measured.

\section{RESULTS AND DISCUSSION \\ X-RAY LUMINESCENCE}

All studied samples of rock-forming quartz of Novosibirsk-Ob Area exhibit luminescence under $\mathrm{X}$ - ray excitation. Table 1 summarizes the data on the XRL of quartz from granitoid massifs of Novosibirsk$\mathrm{Ob}$ Area. It is remarkable that almost all XRL centers, except for $\mathrm{Mn}^{2+}$, are pervasive in case of quartz. Moreover, the scatter of the emission intensities of different massifs is rather small, which may be explained by a common source of mineral formation. In general, these are excited oxygen states on the basis of silicon-oxygen and alumino-oxygen tetrahedra (Table 1)

Figure 2 shows the XRL spectra of quartz from different phases of the $\mathrm{Ob}$, the Novosibirsk and the Kolyvan massifs, in order to emphasize certain distinct features of the formation conditions of these massifs. The $\mathrm{Fe}^{3+}$ band prevails in the XRL spectrum of quartz from the Novosibirsk massif (leucogranites and granosyenite), while in the XRL spectrum of quartz from leucogranites of the Kolyvan and the Barlak massifs the $\mathrm{O}^{*}$ band $(620 \mathrm{~nm})$ is dominant. It may be related to changes in acidic and redox parameters during the melt differentiation and variation in cooling rates.

\section{Calcination effect}

In order to define the luminescence parameters more precisely, apart from the XRL spectra of the initial samples, we recorded the XRL spectra of the samples after a short calcination up to $500{ }^{\circ} \mathrm{C}(5-$ 10 minutes in the usual mode of accessing oxygen in the air). The fact is that after calcination in the XRL spectra of quartz, a band of XRL with a maximum of $370 \mathrm{~nm}$ appears, which is a distinctive feature of these rocks quartz. This band manifested itself most intensively in the XRL spectra of the Novosibirsk Array (Fig. 3, Table 2).

Earlier it was shown that UV glow at $370 \mathrm{~nm}$ in calcined quartz can appear due to the presence of twinning (as a result of $\beta-\alpha$ transitions), which facilitates the concentration of exciton type defects (Boroznovskaya and Bydtaeva, 2003; Boroznovskaya et al., 2016). In addition, the relationship of this band to the oxidative potential was earlier mentioned (Marazuev et al., 1995; Friedrich et al., 2017; Matrosov and Pogorelov, 1977). Thus, this XRL band appearance in quartz can indicate relatively high initial mineral formation temperatures (since $\beta-\alpha$ 
Table 1 A brief description of the possible luminescence centers in the quartz.

\begin{tabular}{|c|c|c|}
\hline Max, nm & Center characteristics & References \\
\hline $320-340$ & Oxygen vacancy & Rink et al., 1993 \\
\hline \multirow[t]{2}{*}{$330-360$} & $\mathrm{AlO}_{4}{ }^{4-} / \mathrm{Na}^{+}, \mathrm{Li}^{+}, \mathrm{H}^{+}$ & Demars et al., 1996 \\
\hline & $\mathrm{TiO}_{4} / \mathrm{Li}^{+}$ & Plötze and Wolf, 1996 \\
\hline \multirow[t]{2}{*}{$360-380$} & Exciton type centers $\mathrm{O}$ & $\begin{array}{l}\text { Boroznovskaya and } \text { Bydtaeva, } \\
\text { Boroznovskaya et al., } 2016\end{array}$ \\
\hline & Interstitial oxygen & Matrosov, Pogorelov, 1977 \\
\hline $370-390$ & $\mathrm{AlO}_{4}^{4-} / \mathrm{Na}^{+}, \mathrm{Li}^{+}, \mathrm{H}^{+}$ & Votyakov et al., 1993 \\
\hline $380-400$ & Matrix defects $\mathrm{SiO}_{2}$ & Tarashchan, 1978 \\
\hline $400-440$ & $\mathrm{SiO}_{4}{ }^{3-} / \mathrm{Na}^{+}, \mathrm{AlO}_{4}{ }^{4-} / \mathrm{Na}^{+}$ & $\begin{array}{l}\text { Kuznetsov and Tarashchan, } \\
\text { Boroznovskaya and Bydtaeva, } 2003\end{array}$ \\
\hline $450-470$ & Matrix defects $\mathrm{SiO}_{2}$ & $\begin{array}{l}\text { Demars et al., 1996, Boroznovskaya et al., 2016, } \\
\text { Gaft et al., } 2005\end{array}$ \\
\hline $470-520$ & $\begin{array}{l}\mathrm{AlO}_{4}^{4-} / \mathrm{Li}^{+} \text {Impurity } \mathrm{Al}^{3+} \text { in place of } \\
\mathrm{Si}^{4+} ; \mathrm{Al} \text { ions may be adjacent to } \mathrm{Al} \text {. }\end{array}$ & $\begin{array}{l}\text { Kuznetsov and Tarashchan, 1988, } \\
\text { Boroznovskaya and Bydtaeva, 2003, } \\
\text { Boroznovskaya et al., 2015 }\end{array}$ \\
\hline $570-590$ & Oxygen vacancy & Götze et al., 2001 \\
\hline 570 & $\mathrm{Mn}^{2+}$ & Kuznetsov and Tarashchan, 1988 \\
\hline 620 & Interstitial oxygen & $\begin{array}{l}\text { Yarovoy, 1996, Götze et al., } \\
\text { Boroznovskaya et al., } 2015\end{array}$ \\
\hline $700-720$ & $\mathrm{Fe}^{3+}$ in place of $\mathrm{Si}^{4+}$ or $\mathrm{Al}^{3+}$ & Kuznetsov and Tarashchan, 1988 \\
\hline
\end{tabular}

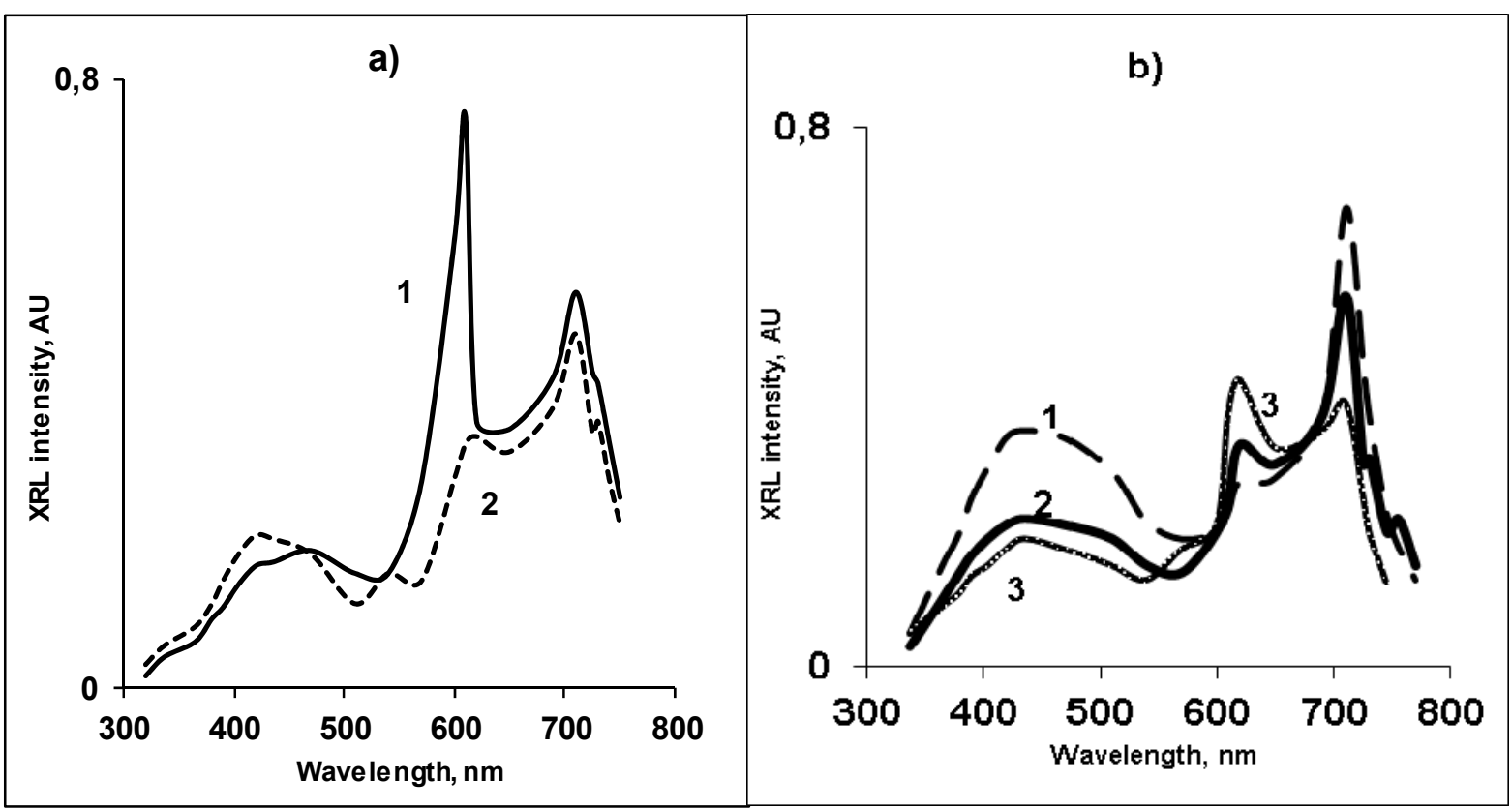

Fig. 2 XRL spectra of rock-forming quartz.

Note. a) The $\mathrm{Ob}$ massif: 1 - biotite-amphibolic granite, 2 - fine-grained granite, b) the Novosibirsk massif: 1 - granosyenite (Borok quarry, sample Br.-7), 2 - leucogranite (Mochishche stock, sample Mc.2; a); the Kolyvan massif: 3 - leucogranite.

transition is possible at the temperature of $573^{\circ} \mathrm{C}$ ) and an increased oxidative potential.

\section{DISCUSSION}

Table 2 presents data on the X-ray luminescence of rock-forming quartz from the KTFB granitoids.

Quartz of the granitoids in Kolyvan-Tomsk folded belt are marked by prominent emission bands of $\mathrm{Fe}^{3+}(710-730 \mathrm{~nm})$ and $\mathrm{O}^{*}(620 \mathrm{~nm})$ (Table 1; Fig. 2). XRL spectra of quartz of the granitoids in Kolyvan-Tomsk folded belt, including intensive XRL of $\mathrm{Fe}^{3+}$ ions, indicate relatively high alkaline conditions within the ore-forming melt. Indeed, oxygen activity in the melt increases markedly as the content of alkali metal, especially potassium, increases (Kutolin, 1972; Nath, 1966). Apparently, 


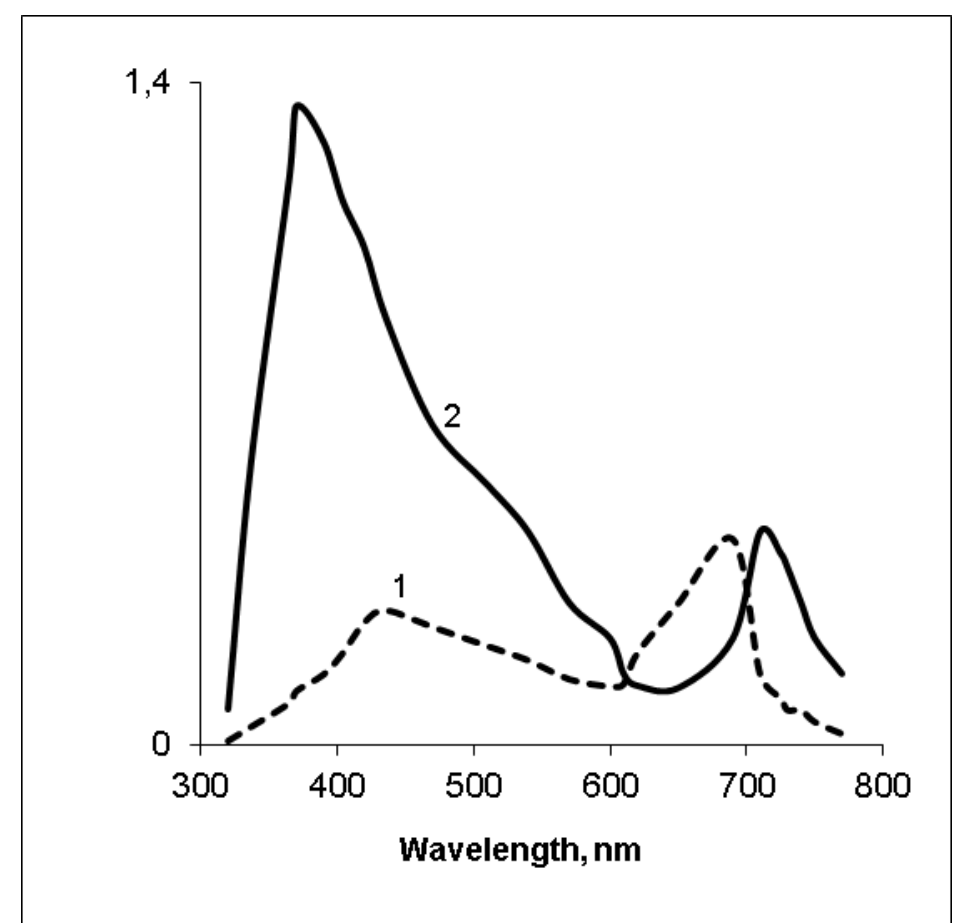

Fig. 3 XRL spectra of rock-forming quartz before (1) and after (2) annealing (the Novosibirsk massif, granosyenite).

Table 2 Averaged data on the X-ray luminescence of rock-forming quartz from the Kolyvan-Tomsk folded belt granitoids.

\begin{tabular}{|c|c|c|c|c|c|c|}
\hline Rocks, phase (Number of samples) & \multicolumn{6}{|c|}{$\begin{array}{l}\text { X-ray luminescence intensity (relative units) in the bands of } \\
\text { maximum radiation (nm) }\end{array}$} \\
\hline $\mathrm{O}^{*}$ & & $\mathrm{O}^{*}$ & $\mathrm{O}^{*}, \mathrm{Mn}^{2+}$ & $\mathrm{O}^{*}$ & $\mathrm{Fe}^{3+}$ & 620 \\
\hline 370 & & $400-490$ & 570 & 620 & $700-720$ & $/ 710$ \\
\hline \multicolumn{7}{|c|}{ Ob massif } \\
\hline Biotite-amphibolic granites, phase 1 (2) & 0.17 & 0.20 & 0.18 & 0.65 & 0.55 & 1.18 \\
\hline Biotite granite, phase 1 (6) & 0.23 & 0.35 & 0.20 & 0.58 & 0.50 & 1.16 \\
\hline Granosyenite, phase 1 (10) & 0.22 & 0.35 & 0.20 & 0.40 & 0.30 & 1.33 \\
\hline Fine-grained granite, phase 2 (11) & 0.17 & 0.25 & 0.21 & 0.50 & 0.30 & 1.67 \\
\hline Aplite-like granite, phase 3 (5) & 0.02 & 0.19 & 0.22 & 0.60 & 0.10 & 6.00 \\
\hline Biotite granite endocontact (10) & 0.11 & 0.17 & 0.21 & 0.40 & 0.70 & 0.57 \\
\hline \multicolumn{7}{|c|}{ Novosibirsk massif } \\
\hline Biotite granite (10) & 1.76 & 0.28 & & 0.15 & 0.60 & 0.25 \\
\hline Granosyenite (10) & 1.85 & 0.38 & & 0.20 & 0.75 & 0.27 \\
\hline \multicolumn{7}{|c|}{ Novosibirsk massif (Mochishche stock) } \\
\hline Leucogranites (10) & 0.9 & 0.36 & & 0.40 & 0.65 & 0.61 \\
\hline \multicolumn{7}{|c|}{ Barlak massif } \\
\hline Leucogranites (10) & 0.22 & 0.30 & 0.10 & 0.40 & 0.30 & 1.33 \\
\hline \multicolumn{7}{|c|}{ Kolyvan massif } \\
\hline Leucogranites (10) & 0.23 & 0.25 & 0.12 & 0.48 & 0.30 & 1.60 \\
\hline $\begin{array}{l}\text { ootnotes: } 1 \text { XRL intensity values in the band } \\
\text { calcined to } 500^{\circ} \mathrm{C} \text {. The other value } \\
\text { 2. The intensity values in each ca } \\
\text { number of which is shown in the fi } \\
\text { not more than } 0.01-0.06 \text {. } \\
\text { 3. XRL spectra were recorded by } \\
1 \mathrm{~nm} / \mathrm{s} \text { speed. XRL intensity value } \\
\text { points, which are maxima related to } \\
720) \text { are given for some luminesce } \\
\text { intensity value also corresponds } \\
\text { Deconvolution andintegration were }\end{array}$ & $\begin{array}{l}\text { f } 370 \mathrm{n} \\
\text { are for t } \\
\text { were } \\
\text { colum } \\
\text { ontinuol } \\
\text { are give } \\
\text { aminesc } \\
\text { intens }\end{array}$ & $\begin{array}{l}\text { from the } \\
\text { iginal quart } \\
\text { hed by find } \\
\text { e deviation } \\
\text { minescence } \\
\text { relative ur } \\
\text { bands give } \\
\text { le to possib } \\
\text { at particula }\end{array}$ & $\begin{array}{l}\text { RL spectra } \\
\text { ng the arith } \\
\text { rom the arit } \\
\text { recording in } \\
\text { ts and show } \\
\text { in the table } \\
\text { lity of maxi } \\
\text { point that }\end{array}$ & $\begin{array}{l}\text { obtaine } \\
\text { letic m } \\
\text { metic } n \\
\text { chosen } \\
\text { lumine } \\
\text { Wave } 1 \\
\text { lum shi } \\
\text { is lum }\end{array}$ & $\begin{array}{l}\text { quartz, wh } \\
\text { or several } \\
\text { or a single } \\
\text { of wave- } \\
\text { intensity } \\
\text { ranges ( } 4 \\
\text { hin these } r \\
\text { nce band }\end{array}$ & $\begin{array}{l}\text { was pre- } \\
\text { ples, the } \\
\text { mple was } \\
\text { ths with } \\
\text { particular } \\
490,700- \\
\text { es (XRL } \\
\text { aximum). }\end{array}$ \\
\hline
\end{tabular}




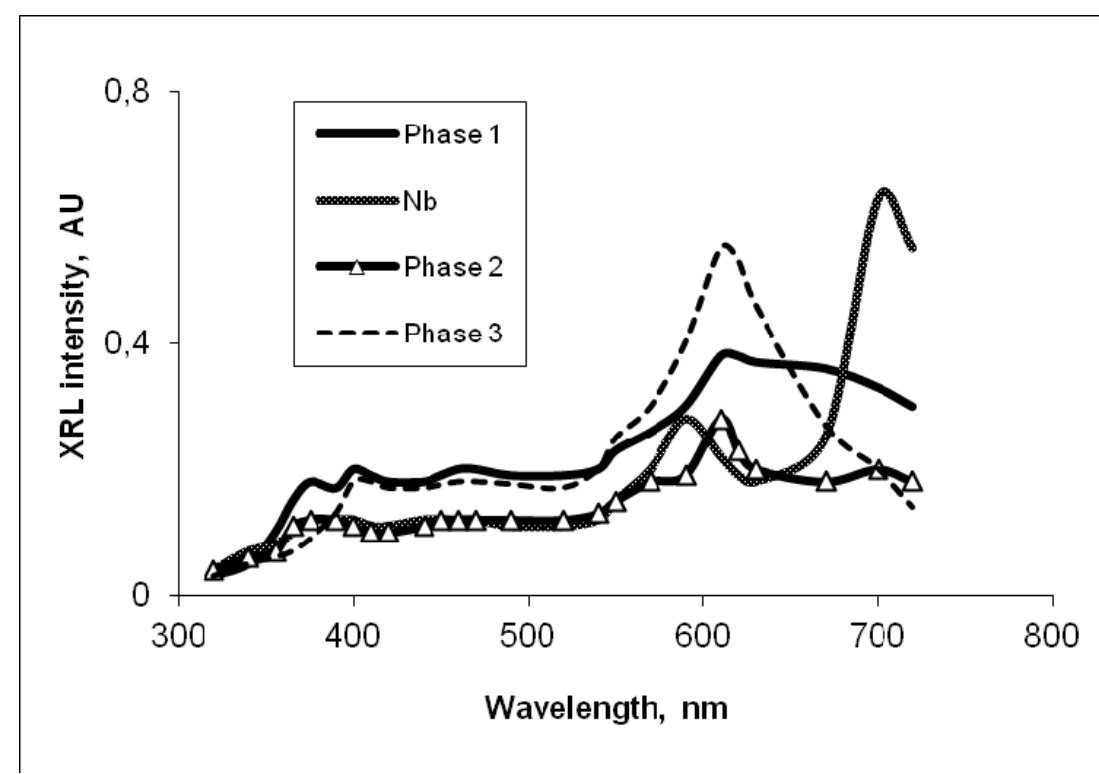

Fig. 4 The specific XRL spectra of quartz for different intrusive phases and endocontactof the $\mathrm{Ob}$ massif ( $\mathrm{Nb}$ - Novobibeevsky quarry). Phases are described in the text. The spectra are constructed based on the averaged data for each phase (see Footnote 2, Table 2).

this circumstance, which in turn ensures increased iron oxidation in alkaline melts, is the cause of intense radiation at $700-720 \mathrm{~nm}$ in quartz. The conclusion about the increased alkalinity of the mineral-forming melt for the KTSZ is confirmed by studies on the composition of biotites (Nebera et al., 2012) and feldspar luminescence (Boroznovskaya et al., 2012). However, it should be noted that the intensity of individual XRL bands varies relatively to each other. It provides an opportunity to implement quartz XRL spectra in solving the problems of the KTFB granitoid classification. Certain intra-massif variations in the XRL intensity are related to multiple phases of the massifs, as it obvious from Table 2 and Figure 2. The ratio of intensities of $620 / 710$ bands turns out to be meaningful. The lowest ratio is observed in quartz of Biotite granite and Granosyenites of the Novosibirsk massif. It can be explained by the proximity of rocks to the enclosing frame, resulting in higher crystallization rate, which has determined the luminescence features of quartz of aplite-like the Novosibirsk massif granites.

As it is evident from Table 2, the $\mathrm{Ob}$ massif main phase quartz XRL spectra are similar to the Kolyvan and the Barlak massifs quartz XRL . They are marked by prominent XRL of intrinsic defects at 370 and 610-620 nm, commeasurable $\mathrm{Fe}^{3+} \mathrm{XRL}$ and emission in 400-500 $\mathrm{nm}$ range, equal for all massifs and related to aluminium centers and intrinsic imperfections. The spectra of the Novosibirsk massif quartz are unique (Figs. 2, 3; Table 2). They are characterized by intense $\mathrm{O}^{*}{ }_{370} \mathrm{XRL}$, which may be due to higher formation temperature of this massif. The same samples are also marked by strong $\mathrm{Fe}^{3+}$ XRL, commeasurable with XRL of endocontact facie of the $\mathrm{Ob}$ massif, which is related to high fugacity of oxygen. It may have occurred during the massif formation in the course of rock crumpling.

As for the XRL spectra of quartz from the rocks of the three phases and the endocontact of the $\mathrm{Ob}$ massif, the following facts should be noted. Prevalence of radiation from $\mathrm{Fe}^{3+}$ (700 nm band) in the XRL spectrum of the endocontact quartz is related to faster cooling and influx of oxygen from the enclosing frame; faint $\mathrm{Fe}^{3+}$ emission in the aplitic quartz (third phase) with intense radiation in the $620 \mathrm{~nm}$ band is most likely due to the final phase formation under conditions of slow cooling and lack of oxygen. With a lack of oxygen, weak radiation can also be associated in the $370 \mathrm{~nm}$ band. The relationship of this XRL band to the oxidative potential was indicated earlier (Matrosov and Pogorelov, 1977). Figure 4 shows the emission bands intensities in the XRL spectra of quartz for different intrusive phases and endocontacts of the $\mathrm{Ob}$ massif.

In general, the spectral composition of quartz radiation from various rocks of the $\mathrm{Ob}$ massif is characterized by a narrow scatter, which indicates the constancy of the physicochemical conditions of crystallization. The quartz XRL similarity of this massif different phases can be a consequence of the mineralization that is close in time and conditions. The exception is the third phase. The quartz luminescence of the third phase features can be associated with a discontinuity in time between the second and third phases, with the depletion of the mineral-forming medium by oxygen, with a change in the oxidation potential.

\section{THERMOLUMINESCENCE}

Natural thermoluminescence (TL) of studied quartz samples within the range of $180-320^{\circ} \mathrm{C}$ may be 


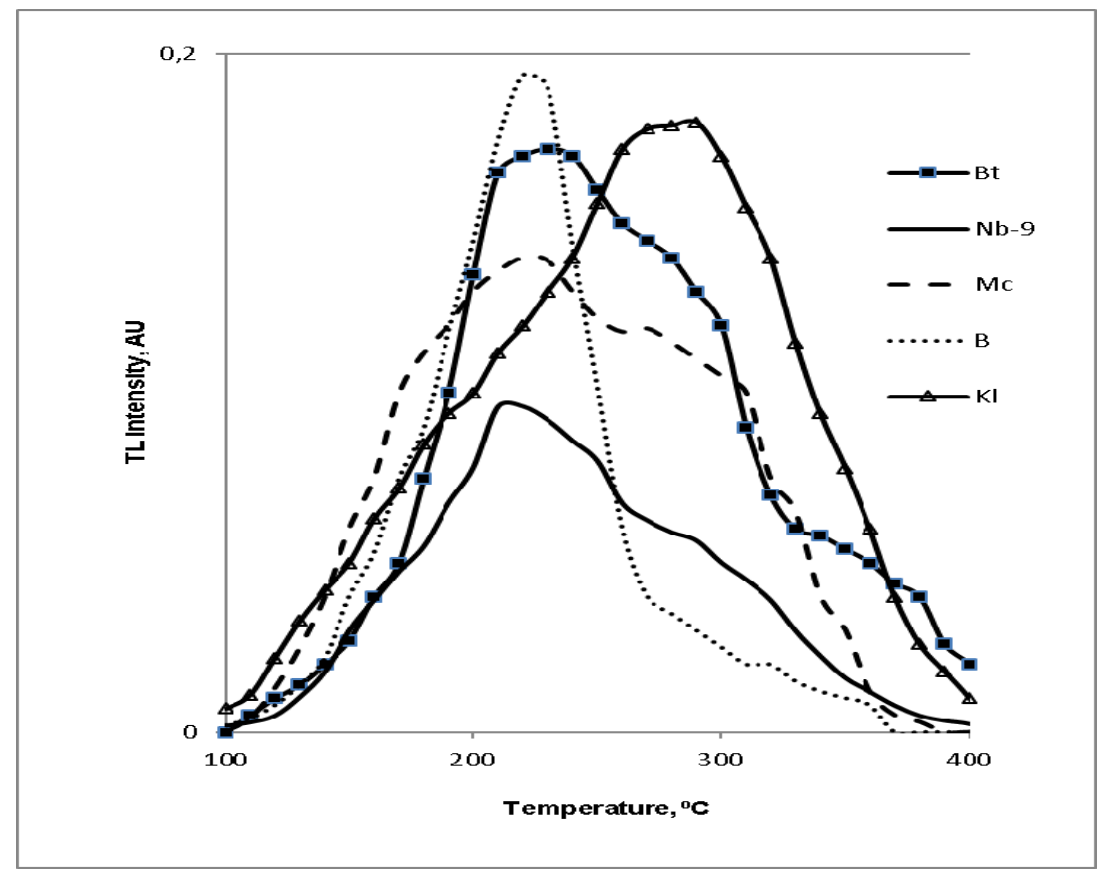

Fig. 5 Thermoluminescence curves of quartz from the Kolyvan-Tomsk folded belt granitoids. The $\mathrm{Ob}$ (sample $\mathrm{Nb}-9$, granosyenite, $\mathrm{Bt}$, granite), the Novosibirsk (sample B, granosyenite), Moschische stock (sample Mc, leucogranite), The Kolyvan (sample Kl, leucogranite) massifs.

due to presence of $\mathrm{Al}, \mathrm{Ge}, \mathrm{Li}, \mathrm{Na}$ inclusions (Boroznovskaya et al., 2016; Pogorelov et al., 1979; Rink et al., 1993). Such a preservation of the light sum is most likely a consequence of an increased radiation background, which is a characteristic of granitoids. There are two broad peaks in the ranges of $180-240{ }^{\circ} \mathrm{C}$ (T1) and $260-300{ }^{\circ} \mathrm{C}$ (T2). The curve character is determined by the ratio between these maximums (Fig. 5). Prevalent emission at $180-220^{\circ} \mathrm{C}$ in case of quartz from granosyenites of the Novosibirsk massif (Fig. 5, sample B) is related to increased number of clusters of $\mathrm{Ge} / \mathrm{Li}$ centers within the capture range of "Al" luminescence centers (Pogorelov et al., 1981). This scenario suggests high concentrations of "Al"-centers as well, which may be the result of higher temperatures of mineral formation. TL of quartz from leucogranites of the Kolyvan massif has different nature (Fig. 5, sample K1). In this case, the intensity of T2 $\left(260-300{ }^{\circ} \mathrm{C}\right)$ is often higher than that of $\mathrm{T} 1\left(180-240{ }^{\circ} \mathrm{C}\right)$ with total light sum being shifted towards higher temperature range, which is related both to uncoupling of $\mathrm{Ge} / \mathrm{Li}$ and "Al" centers and to involvement of $\mathrm{Na}$ in the formation of TL centers, which may be the result of slow cooling of this massif. Geological data suggest that the Kolyvan massif is the most low-temperature one among the Novosibirsk-Ob Area granitoids.

Figure 6 shows luminescence curves of quartz from rocks of different phases and the endocontact of the $\mathrm{Ob}$ massif. The spectra of rocks of all phases are virtually identical, marked by a broad peak at 200$300{ }^{\circ} \mathrm{C}$. This fact provides additional evidence for the conclusion on similar formation conditions for the rocks of different phases and the endocontact of the $\mathrm{Ob}$ massif.

\section{CONCLUSIONS}

The research makes it possible to elucidate features of the mineral formation conditions in the course of granitoid intrusions establishment within the collision areas of island-arc and subcontinental terrains. Studies on the sub-microscopic defects of rock-forming quartz of the Novosibirsk-Ob Area granitoids with the help of luminescence analysis led us to the following conclusions:

- Quartz luminescence of the examined granitoids is the result of the certain temperature of mineral formation and cooling rate.

- Identical of quartz XRL and TL from the granitoids of different massifs can be the result of similar conditions and mechanisms of the granitoids formation with close periods of establishment within the Novosibirsk-Ob area.

- The Novosibirsk massif XRL and TL quartz individuality was manifested in the intense XRL of $\mathrm{Fe}^{3+}$ and TL at $180-220^{\circ} \mathrm{C}$, due to increased concentrations of $\mathrm{Ge} / \mathrm{Li}$ centers inside the capture sphere of "Al" luminescence centers. This could be due to the high fugacity of oxygen, the increased temperature and the mineral formation rate in the crushing of rocks regime under tectonically active zone conditions.

All these suggestions are compliant with previous conclusions from the X-ray luminescence of feldspar on common source of the Novosibirsk-Ob 


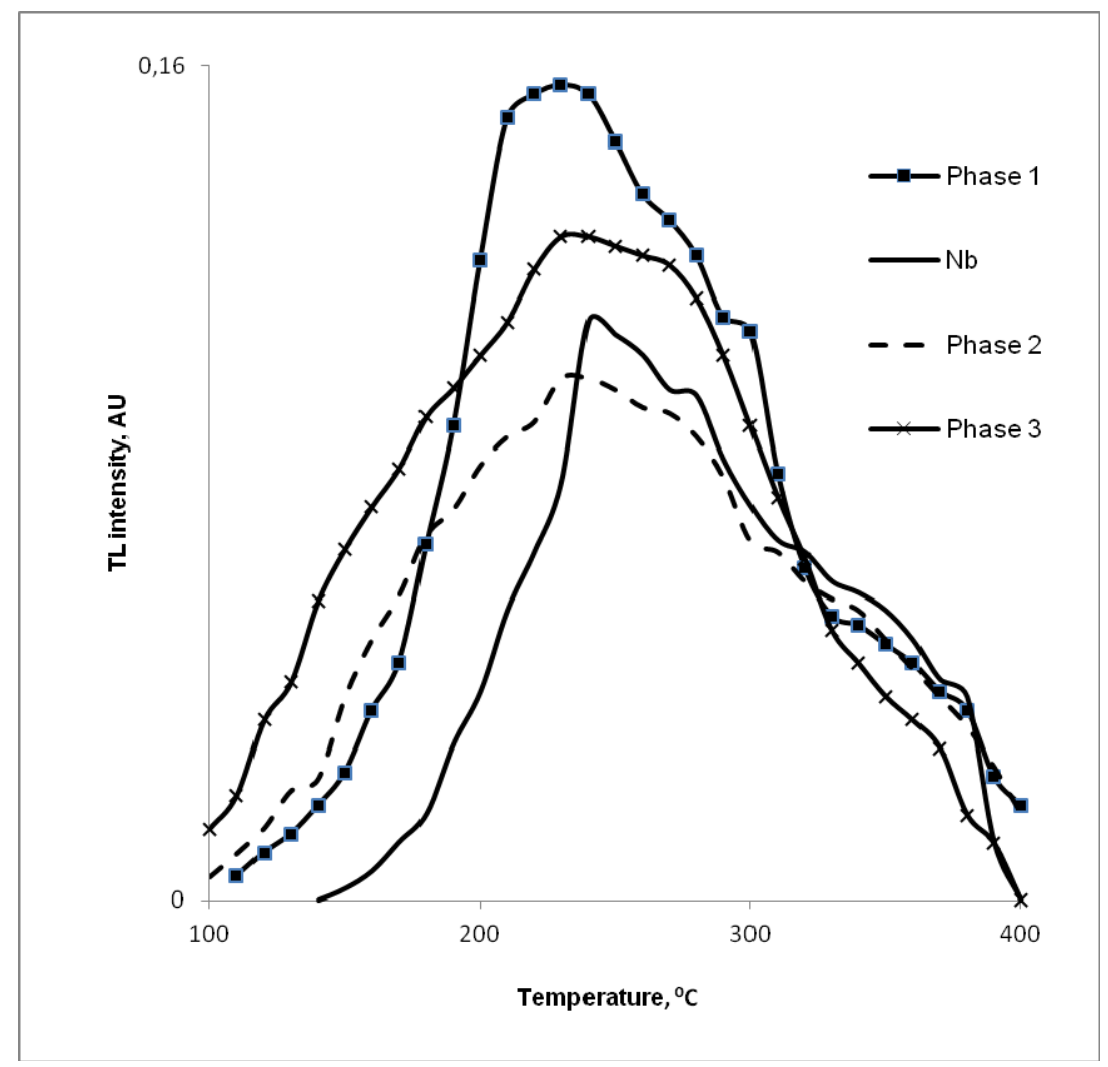

Fig. 6 Types of thermoluminescence curves of quartz from the rocks of different phases and the endocontactof the $\mathrm{Ob}$ massif $(\mathrm{Nb}$ Novobibeevsky quarry). Phases are described in the text.

Area granitoids formation (Boroznovskaya et al., 2012), which allows us to consider the KTFB granitoid magmatism as the result of natural magmatic differentiation of the parental magma, providing a viable possibility to implement the quartz emission spectra in solving the problems of typification of granitoid massifs and other geological formations. At the same time, the data provides evidence for the differences in the leucocratic magmatism of the area, allowing classification of the Kolyvan-Tomsk folded belt leucogranites into the leucogranites of the Novosibirsk massif (Mo-W type of mineralization) and the leucogranites of the Kolyvan and the Barlak massifs characterized by rare metal mineralization (stannic-tungstic-beryllic with silver).

\section{ACKNOWLEDGEMENT}

The study is supported by the Ministry of Education and Science of the Russian Federation, government task №2282.

\section{REFERENCES}

Bazhenov, A.I., Poluektova, T.I. and Novoselov, K.L.: 2003, Petrogenezis granitoids of the Baturinsky massif and their potential ore content (KTFB). Contemporary problems of formation analysis, petrology and orebearing magmatic formations. SO RAN Publ., Novosibirsk, Russia, 35-36, (in Russian).
Boroznovskaya, N.N. and Bydtaeva, N.G.: 2003, Implementation of luminescence in detection of microscopic defects for the assessment of raw quartz quality. Ore deposits, mineralogy, geochemistry. Department of Mineralogy and Geochemistry, TSU, Tomsk, Russia, 12-27, (in Russian).

Boroznovskaya, N.N.: 1989, X-ray luminescence of feldspar as an indicator of its genesis. International Geology Review, 31, 4, 395-403, (in Russian).

Boroznovskaya, N.N., Bydtaeva, N.G. and, Korneva, A.P.: 2015, Luminescence analysis of raw quartz quality. Tomsk: TsNTI, Tomsk, Russia, 101 pp., (in Russian).

Boroznovskaya, N.N., Korneva, A.P. and Marfin, A.E.: 2016, Structural impurities and intrinsic defects role in high quality raw quartz selection by use of luminescence analyses. Key Engineering Materials, 683, 168-173, (in Russian).

Boroznovskaya, N.N., Nebera, T.S., Konovalenko, S.I. and, Novoselov, K.L.: 2012, Genetic and crystallochemical informativeness of X-ray luminescence of feldspars from the granitoids of Kolyvan-Tomsk folded belt. Zapiski RMO, 2, 91-101, (in Russian).

Demars, C., Pagel, M., Deloule, E. and Blanc P.: 1996, Cathodoluminescence of quartz from sandstones: interpretation of the UV range by determination of trace element distribution and fiuid-inclusion P-T-X properties in authigenic quartz. Amer. Miner., 81, 891-901. DOI: 10.2138/am-1996-7-812

Dobretsov, N.L.: 1997, Permian-Triassic magmatism and sedimentation in Eurasia as superplume reflection response. Proceedings of RAS, 354, 2, 220-223, (in Russian). 
Dobretsov, N.L.: 2003, Mantle plumes and their role in the formation of anorogenic granitoids. Geology and Geophysics, 44, 12, 1243-1261, (in Russian).

Friedrich, J., Pagonis, V., Chen, R., Kreutzer, S. and Schmidt, C.: 2017, Quartz radiofluorescence: a modelling approach. Journal of Luminescence, 186, 318325. DOI: 10.1016/j.jlumin.2017.02.039

Gaft, M., Reisfeld, R. and Panczer G.: 2005, Modern luminescence spectroscopy of minerals and materials. Springer-Verlag Berlin Heidelberg, Germany, XVI, $356 \mathrm{pp}$.

Gorobets, B.S. and, Rogozhin, A.A.: 2001, Guidebook of mineral luminescence spectra: - VIMS, Moscow, Russia, 312 pp., (in Russian).

Götze, J., Plötze M. and Habermann, D.: 2001, Origin, spectral characteristics and practical applications of the cathodoluminescence (CL) of quartz - a review. Mineralogy and Petrology, 71, 225-250. DOI: $10.1007 / \mathrm{s} 007100170040$

Hayes, W.: 1990, The structure of the self-trapped exciton in quarts. Rev Solid State Sci., 4, 543-546.

Jani, M.G., Bossoli, R.B. and Halliburton, L.E.: 1983, Further characterization of the E01 center in crystalline SiO2. Phys. Rev., B27, 2285-2293.

Khomichev, V.L. (ed.): 2007, Updated schemes of interregional and regional correlation of magmatic and metamorphic complexes of the Altai-Sayan folded belt and the Yenisei range. SNIIGGiMS, Novosibirsk, Russia, 280 pp., (in Russian).

Khomichev, V.L., Nikonov, Yu, N. and Antonovich, R.M.: 2003, Reference material on the Borok-Bibeevo gabbrogranitoid complex (the Kolyvan-Tomsk Area): SNIIGGiMS, Novosibirsk, Russia, 244 pp., (in Russian).

Kutolin, V.A.: 1972, Problems of petrochemistry and petrology of basalts. Nauka, Novosibirsk, Russia, 208 pp., (in Russian).

Kuznetsov, G.V. and Tarashchan, A.N.: 1988, Luminescence of mineral from granite pegmatites: Naukova Dumka, Kiev, Ukraine, 178 pp., (in Russian).

Lyutoev, V.P.: 2008, Genetic and material testing meaning of structural defects in crystallic-granular quartz. - In: Minerals and mineral formation, structure, diversity and evolution of mineral world, role of minerals in life origin and evolution, biomineral interactions. Geoprint, Syktyvkar, Russia, 124-189, (in Russian).

Marazuev, Y., Brik, A. and Degoda, V.: 1995, Radioluminescent dosimetry of [alpha]-quartz. Radiation Measurements, 24, 565-569.

Matrosov, I.I. and Pogorelov, Yu.L.: 1977, Impact of annealing on X-ray luminescence spectra of quartz. Proceedings of the USSR Academy of Sciences, Geology, 9, 89-94, (in Russian).

Nath, P.: 1966, The effect of glass composition on redox equilibria and oxygen ion activity in glassen-glass and Ceram. Bull., 13, 2, 41 .

DOI: $10.1016 /$ j.chemgeo.2004.08.037

Nebera, T.S. and Boroznovskaya, N.N.: 2009, Typomorphic value of structural and chemical features of potassium feldspar from granitoids of the Novosibirsk Ob region (KTFB). Bulletin of Tomsk State University, 325, 206-211, (in Russian).
Nebera, T.S. and Boroznovskaya, N.N.: 2012, Typomorphism of rock-forming minerals of the Kolyvan-Tomsk folded belt. In: 2012 annual meeting of RMO and Fedorov session, October 9-11 2012, LEMA publ., Saint-Petersburg, Russia, 201-203, (in Russian).

Nebera, T.S. and Boroznovskaya, N.N.: 2013, Geochemical features of granitoid Central Siberia magmatism in the Permian-Triassic. Goldschmidt Conference Abstracts, P. 18, (in Russian).

Nebera, T.S., Boroznovskaya, N.N. and Konovalenko, S.I.: 2012, Evolution of granitoid magmatism of the Kolyvan-Tomsk folded belt (based on the studies of $\mathrm{Mg}-\mathrm{Fe}$ mica composition). Proceedings of the Academy of Sciences, 442, 6, 810-813, (in Russian).

Nuvar'eva, Yu.A.: 1968, On the depth facies and metallogenic features of the granitoid massifs of the Kolyvan-Tomsk folded belt. Updates on magmatism and ore content of the Altai-Sayan folded belt, Novosibirsk, Russia, 155-159, (in Russian).

Pagel, M. et al.: 2000, Cathodoluminescence in Geosciences: An Introduction. In: Pagel, M., Barbin, V., Blanc, P., Ohnenstetter, D. (Eds.): Cathodoluminescence in geosciences, Springer-Verlag Berlin Heidelberg, Germany, 1-19.

Pagonis, V., Chen, R. and Wintle, A.G.: 2007, Modelling thermal transfer in optically stimulated luminescence of quartz. Journal of Physics D., Applied Physics., 40, 4, 998-1006. DOI:10.1088/0022-3727/40/4/012

Pogorelov, Yu.L., Mashkovtsev, R.I. and, Tarashchan, A.N.: 1981, Role of certain paramagnetic defects in thermoluminescence of natural quartz. Journal of Applied Spectroscopy, 34, 6, 1084-1087, (in Russian).

Pogorelov, Yu.L., Matrosov, I.I. , and Mashkovtsev, R.I.: 1979, Study of radiation defects in quartz induced by beta-particles, with the help of EPR and thermosluminescence. News of Higher Educational Institutions. Physics, 2, 110-112, (in Russian).

Rakov, L.T. and Moiseev, B.M.: 1999, Potential of EPRspectroscopy in the assessment of raw quartz quality. Prospect and protection of mineral resources. 3, 2122, (in Russian).

Rink, W.J., Rendell, H., Marseglia, E.A., Luff, B.J. and Townsend, P.D.: 1993, Thermoluminescence spectra of igneous quartz and hydrothermal vein quartz. Phys Chem Minerals, 20, 353-361. DOI: $10.1007 / \mathrm{BF} 00215106$

Rokachuk, T.A.: 2006, Typomorphism of Salic rockforming minerals from Pre-Cambrian enderbitoids and charnokite (based on the study of quartz and feldspar luminescence). Mineralogical Journal, 28, 3, 91-105, (in Russian).

Sotnikov, V.I., Fedoseev, G.S., Kungurtsev, L.V. et al.: 1999, Geodynamics, magmatism and metallogeny of the Kolyvan-Tomsk folded belt: SO RAN, NITs OIGGM. Novosibirsk, Russia, 227 pp., (in Russian).

Votyakov, S.L., Krokhalev, V.Ya., Purtov, V.K. and Krasnobaev, A.A.: 1993, Luminescence analysis of structarl imperfections in quartz: UIF "Nauka", Ekaterinburg, Russia, 70 pp., (in Russian).

Yarovoi, P.N.: 1996, Laser diagnostics of luminescent substances: Izd-vo IGTU, Irkutsk, Russia, 176 pp., (in Russian). 